\title{
The spatial logics of justification - The case of a dispute over a car-free street in Tampere, Finland
}

\author{
Jarkko Salminen
}

Faculty on Social Sciences, University of Tampere, Tampere, Finland

This article advances the spatial aspect of the justification theory of Luc Boltanski and Laurent Thévenot. The aim is to show that the worlds of justification, distinct entities of moral values and material objects, have also distinct spatial logics. To illustrate my argument, I use a case study, namely, a polarized dispute related to a car-free main street in Tampere, the third biggest city in Finland. I show that the spatial logics in this dispute are ordered by different types of image schemas, recurrent and shared visuospatial patterns depicted by George Lakoff and Mark Johnson. I analyse image schemas to make visible the differences and similarities between the worlds of justification. Advancing the spatial aspect of the justification theory enables a novel way to study disputes related to city and space, as well as controversies that are not obviously spatial. Human thinking is multimodal and entails visuospatial metaphors, although its subject would seem non-spatial.

Keywords: Space, city, cars, justification theory, image schema, visuospatial metaphors

\section{Introduction}

In this article, I develop the spatial aspect of the justification theory of Boltanski and Thévenot. The aim is to illustrate how people reason spatially and use spatial metaphors as they argue and justify their views (see Johnson, 1987; Lakoff, 1987; Oakley 2005; Turner 1991). The material aspect of justification theory, namely, how people refer to material objects that are used as stable referents in disputes, has been explicitly addressed (Boltanski \& Thévenot, 1999, p. 360-367; Boltanski \& Thévenot, 2006, p. 130-138) and empirically 
studied. Different types of technical devices (Mailhot el al., 2016, p. 74), foods (Yamaguchi \& Suda, 2010), buildings (Oldenhof, Potsma, \& Putters 2014) and roads (Thévenot, 2002) have been proposed to represent different types of values that become materialized and solidified in these objects, for example, a small house can be cosy and cost-effective (Oldenhof et al., 2014). However, the spatial aspect of justification, the role of the space around and inside the objects, has not been explicitly observed.

As people justify their views, they draw upon worlds of justification, which are separate entities of moral values that cannot be reduced to one another (Boltanski and Thévenot, 2006, p. 131). Worlds of justification have a material aspect, namely, separate set objects that represent their values and guarantee their existence as solid physical bodies that people can refer to. The aim of this article is to show that the worlds also have distinct spatial logics that can function as tools to make values manifest. For example, people can refer to the importance of objects at home or in their hometown to emphasize domestic values, but they can also refer to the importance of closed and protected spaces for the same purpose. Moreover, people can refer to the importance of technical devices to ensure efficiency, but they can also refer to the importance of space organized adequately to reach goals efficiently.

To illustrate how people reason spatially as they justify their views, I analyse a case study of a controversy that is related to transforming Hämeenkatu, the main street in Tampere, Finland, to a car-free street. Tampere, the $3^{\text {rd }}$ largest city in Finland with over 230000 inhabitants, is in the middle of radical and large-scale traffic-related construction projects, which have polarized local disputes. By analysing an argumentation that occurred on the Internet forum of a local newspaper, Aamulehti, I look for different kinds of spatial logics. For example, a spatial logic emerges when a person argues that the idea of a car-free street does not improve the image of the city from the perspective of outsiders but threatens the inner order, stability and traditions of the city. Another spatial logic emerges when a person 
argues that spending time moving in and wandering around urban space should not be an endin-itself, but driving or walking in the city should be a means to reach a goal efficiently.

What separates these spatial logics? They are based on different cognitive understandings of space. In the first logic, one is inside (the city); in the second, one is on the way (towards a goal). To be able to understand space and refer to it in a dispute, arguments have to be anchored to image schemas, simple visuospatial patterns that organize the flow of information and perceptions of space. Image schemas are used to process information, order conceptions and make sense of the world (Johnson, 1987; Lakoff, 1987). They are recurrent and shared, which enables them to be used as solid and stable referents in disputes. By analysing the data and sketching different image schemas, one can see the spatial differences and similarities between the worlds of justification. Later in this article, I depict the plurality of the kind of schemas used in justification.

To illustrate how people use spatial reasoning as they justify their views, a car-free street is a workable case because the main street in a city always has great symbolic meaning, and a multitude of values are present in a city; therefore, parties justify their views diversely (Albertsen \& Diken, 2001, p. 21; Blok, 2013, p. 501-503; cf Thévenot, Moody \& Lafaye, 2000 , p. 230). Moreover, the spatial role of cars in a city is very problematic. Cars dominate street space (Dant \& Martin, 2001, p. 154), and there is an ongoing struggle between the people who use different modes of transport (Aldred \& Jungnickel, 2013). Nevertheless, the number of cars in Europe (Asociación Española de Fabricantes de Automóviles y Camiones [ANFAC] 2014) and in Finland (Statistics Finland, 2013) has been growing.

An analysis of the spatial aspect behind the justification theory may open new directions for its application. It has been suggested that justification theory can provide a new perspective that emphasizes the plurality of values in spatial research, such as planning research (Holden \& Scerri, 2015) or geography (Barnett, 2014; Fuller, 2012). This theory may 
be 'more hospitable to a wider diversity of attachments to the city' (Blok \& Meilvang, 2015, p. 21). For example, justification theory can provide an understanding of the diversity of positive and negative values that people attach to cars in the city. However, considering the spatial aspect of Boltanski's and Thévenot's theory also can open new ways to analyse many kinds of controversies that seem non-spatial at first glance because people also use spatial reasoning and metaphors in disputes related to topics that are not clearly spatial subjects.

The structure of this article is as follows. First, I present the justification theory and worlds of justification from a spatial perspective. Then, I explain how people reason spatially and use image schemas, recurring visuospatial patterns, to make sense of the space and world around them. Next, I present the Tampere case and previous car-related research. After this, I present the data and methods and describe the special features of the online discussion data from the perspective of studying public disputes. In the analysis section, I use the empirical data of the car-free street to illustrate the spatial logics participants use in their argumentation and the image schemas they are based on. Finally, I contemplate the implications of my argument for justification theory and the novel ways it can be used in the future.

\section{Space in the worlds of justification}

Boltanski and Thévenot (1999, p. 361) build their theory from the idea of critical moments in which participants rely on shared moral values. For example, if a car collision occurs, a person cannot explain what happened by pleading that he or she has a bad day or health concerns that cause him or her not to be cautious. These personal explanations for the collision are not considered legitimate; instead, one should rely on explanations that are based on shared moral values. Simultaneously, people should refer to relevant material objects such as traffic signs or the condition of the tires that are accepted to be legitimate points of reference. These material objects ensure social stability because people share a similar 
understanding of their value. For example, one can argue that the other person should have followed traffic signs that guarantee order in traffic or that his or her worn out tires make a car impossible to control.

Shared moral values and corresponding material objects together form separate entities called worlds of justification. These worlds cannot be reduced to one another, and objects are their solid representatives that guarantee their existence and separateness. "Objects that constitute tools for making the worth of persons manifest in one world may not be taken into account at all in a different world" (Boltanski and Thévenot, 2006, p. 131). The worlds of justification are the industrial world, world of inspiration, domestic world, world of renown, market world and civic world ${ }^{1}$. Boltanski and Thévenot (2006, p. 159-211) do not describe the spatiality of these worlds explicitly, although one can interpret it from their texts (Table 1). In the domestic world, a stable home environment is protected. In the world of renown, outside opinion is valued. In the industrial world, valued space is a means to reach a goal. In the world of inspiration, space is an end-in-itself. In a market world, space is an arena for competition. In the civic world, space is a public forum.

In the context of cars and traffic, Thévenot's (2002) illustration of a road offers a way to clarify the differences among the worlds of justification from a spatial perspective. Thévenot (2002) has studied how a road in the French Pyrenees incorporates political and moral qualities and thus participates in the actualization of different shared moral values. Moreover, Thévenot, Moody \& Lafaye (2000) have compared environmental disputes in France (road and tunnel project) and the United States (dam project), which led them to summarize how in these cases space is formed in worlds of justification (by qualified human beings and objects). In this article, I start from the observation that worlds of justification have distinct spatial characteristics (for example, in the industrial world, space is Cartesian, 
standardized, and located in coordinates) but continue to examine more closely how people reason spatially using different image schemas in different worlds of justification. 


\begin{tabular}{|c|c|c|c|}
\hline $\begin{array}{l}\text { World of } \\
\text { justification }\end{array}$ & $\begin{array}{l}\text { Spatial logic (interpretation } \\
\text { from Boltanski \& Thévenot, } \\
\text { 2006, p. 159-211) }\end{array}$ & $\begin{array}{l}\text { Example of a road } \\
\text { (Thévenot, 2002) }\end{array}$ & $\begin{array}{l}\text { Space formation (by } \\
\text { qualified objects, human } \\
\text { beings) (Thévenot, } \\
\text { Moody \& Lafaye, 2000) }\end{array}$ \\
\hline $\begin{array}{l}\text { Industrial } \\
\text { world }\end{array}$ & $\begin{array}{l}\text { Space is controlled by experts } \\
\text { who make calculations (space } \\
\text { is a means to reach ends) }\end{array}$ & $\begin{array}{l}\text { A road is valuable as } \\
\text { standardized and located } \\
\text { in coordinates }\end{array}$ & $\begin{array}{l}\text { Infrastructure, technical } \\
\text { objects and plans are } \\
\text { developed by engineers } \\
\text { and experts who work in } \\
\text { Cartesian space }\end{array}$ \\
\hline $\begin{array}{l}\text { World of } \\
\text { inspiration }\end{array}$ & $\begin{array}{l}\text { Spontaneous and uncontrolled } \\
\text { source for imagination (space } \\
\text { is an end-in-itself) }\end{array}$ & $\begin{array}{l}\text { A 'path' that leads to } \\
\text { places and visions that are } \\
\text { unimaginable }\end{array}$ & $\begin{array}{l}\text { Creative beings use } \\
\text { emotionally invested } \\
\text { items to deepen the } \\
\text { presence in space }\end{array}$ \\
\hline $\begin{array}{l}\text { Domestic } \\
\text { world }\end{array}$ & $\begin{array}{l}\text { Familiar, stable and traditional } \\
\text { home environment that is } \\
\text { organized by rules to protect it } \\
\text { from the threatening and alien } \\
\text { outside (inward-oriented) }\end{array}$ & $\begin{array}{l}\text { A road leads to home and } \\
\text { is the familiar centre of } \\
\text { the world, which is shared } \\
\text { by the locals, and its } \\
\text { proximity makes it } \\
\text { valuable }\end{array}$ & $\begin{array}{l}\text { Authorities value } \\
\text { patrimony and heritage, } \\
\text { which are anchored } \\
\text { locally, proximally }\end{array}$ \\
\hline $\begin{array}{l}\text { World of } \\
\text { renown }\end{array}$ & $\begin{array}{l}\text { People value the opinions of } \\
\text { outsiders, who are famous and } \\
\text { gain recognition from as far } \\
\text { away as possible (outward- } \\
\text { oriented) }\end{array}$ & $\begin{array}{l}\text { Part of a beautiful scenery } \\
\text { that is targeted especially } \\
\text { to tourists who recognize } \\
\text { its image from far away }\end{array}$ & $\begin{array}{l}\text { Celebrities use media to } \\
\text { access communication } \\
\text { networks }\end{array}$ \\
\hline $\begin{array}{l}\text { Market } \\
\text { world }\end{array}$ & $\begin{array}{l}\text { A resource that should be freed } \\
\text { to private competition and that } \\
\text { in the end, benefits everybody } \\
\text { (an arena for competition) }\end{array}$ & $\begin{array}{l}\text { A source of profits, for } \\
\text { example, through road } \\
\text { tolls }\end{array}$ & $\begin{array}{l}\text { Goods are circulated } \\
\text { freely by sellers and } \\
\text { customers in globalized } \\
\text { markets }\end{array}$ \\
\hline Civic world & $\begin{array}{l}\text { People, regardless of their } \\
\text { positions, wealth and physical } \\
\text { distance, should be equal in } \\
\text { space (an open forum) }\end{array}$ & $\begin{array}{l}\text { An open passage for } \\
\text { everyone that creates } \\
\text { regional equality }\end{array}$ & $\begin{array}{l}\text { Rules, regulations, rights } \\
\text { and policies ensure } \\
\text { equality of detached } \\
\text { citizens }\end{array}$ \\
\hline
\end{tabular}

Table 1. Spatial logics, the road example and space formation in the worlds of justification 
In addition to the original six worlds of justification, Thévenot, Moody \& Lafaye (2000) have established seventh world, the world of ecology, in which nature has intrinsic value.

Moreover, Boltanski and Chiapello (2007) have construed the projective world in which networking, flexibility and contacts are valued. There is no final number of the worlds of justification because new worlds can form and be found. ${ }^{2}$

Previous examples (Boltanski \& Thévenot, 1999, p. 361; Thévenot 2002; Thévenot, Moody \& Lafaye 2000) show how objects can have a role in disputes and can incorporate values. For example, different types of buildings can incorporate different types of values, and buildings can be domestic family-size homes in normal residential areas (civic/domestic) or large efficient and profitable communal buildings with small individual apartments (market/industry) (Oldenhof et al., 2014). It is clear that objects have roles in disputes; however, there are also some types of spatial patterns (inward-outward). Roads and buildings are not only static material objects that consist of walls, floors and roofs but also spatial entities that enable some spatial patters and prevent others.

In this article, I focus on different spatial logics behind the worlds of justification. This focus leads me to interpret and illustrate empirically that the worlds form pairs that have spatial logics that are opposite of one another. Domestic space is inward-oriented, and the space that is related to renown is outward-oriented. Industrial space is a means to an end, and inspirational space is an end-in-itself. In the space that is based on market value, people and objects are set in hierarchic order, and in civic space, all people are on the same level. Next, I focus on what the pairs with opposite spatial logics share and what separates them from other pairs. For example, what unites the industrial world and the world of inspiration? Why, for example, is this industrial-inspiration pair (space as means to an end vs. an end-initself) different from the domestic-renown pair (inward vs. outward oriented) ${ }^{3}$ ? I then define the concept of an image schema. I show that the worlds of justification that have opposite 
spatial logics share the same image schema. Later, I use a case of the dispute that is related to a car-free street in Tampere, Finland to illustrate empirically the contrast between opposite spatial logics and corresponding image schemas.

\section{Spatial logics and image schemas}

The worlds of justification can be separated on the basis of different forms of spatial logics. According to Lakoff and Johnson (1999), logical reasoning is not only based on language but is multimodal and visuospatial (see also Swedberg, 2016). People can utilize various forms of image-making, such as photography, drawings and maps, to justify their views (Blok \& Meilvang, 2015); however, instead of studying these types of actual images used to support arguments, I study image schemas that order the argumentation. Image schemas are recurrent and shared visuospatial patterns that organize the world cognitively. They are simple diagrams of how the world is structured (Turner, 1991, p. 171) ${ }^{4}$. Schemas enable the processing of large amounts of information pouring from the surrounding space and packaging it in a way that makes sense to the individual and collective. Image schemas enable abstract thinking because they are a basis for spatial metaphors that originate from shared ways in which people perceive material and spatial reality.

'In order for us to have meaningful, connected experiences that we can comprehend and reason about, there must be pattern and order to our actions, perceptions, and conceptions. A schema is a recurrent pattern, shape, and regularity in, or of, these ongoing ordering activities. These patterns emerge as meaningful structures for us chiefly at the level of our bodily movements through space, our manipulation of objects, and our perceptual interactions' (Johnson, 1987, p. 29, italics in original).

Researchers have proposed image schemas such as container, source-path-goal, blockage, center-periphery, cycle, link, scale, contact and rotation (Johnson, 1987; Lakoff, 1987). I 
narrow the field somewhat and utilize three image schemas that best help to interpret the differences and similarities among the worlds of justification. These image schemas are container, source-path-goal and what I call the vertical scale schema. People use image schemas in their argumentation in two intertwined ways, on the one hand, when they describe literally what the actual physical space should be like, and on the other hand, when they represent space figuratively, in other words, when they use visuospatial metaphors to justify their views. I first present the idea of the image schemas behind the worlds of justification on an abstract level and later use the empirical data to demonstrate how people in reality justify their views by using image schemas as shared and stable referents in disputes.

The container schema constitutes the basis for the spatial logics of the domestic world and the world of renown in opposite ways (Lakoff \& Johnson, 1999, p. 31-32) (Table 2). In the domestic world, the interior of the home and the home environment is a closed container that should be protected from outside threats with local traditions, rules and internal order. On the contrary, in the world of renown, the outside is valued because the positive opinions of outsiders are important. In the empirical section, I contrast the inwardness of the domestic world with the outwardness of the world of renown.

The source-path-goal schema is the basis for the spatial logics of the industrial world and the world of inspiration in opposite ways (Lakoff \& Johnson, 1999, p. 32-34). In the industrial world, the purpose is to efficiently achieve predefined goals in a controlled and calculated way. Space is means to an end. In the world of inspiration, the essence is the path, and space as an end-in-itself, a spontaneous mental or physical journey with unexpected encounters and spending time in space. Later, by using the empirical data, I contrast industrial space as means to an end and inspirational space as an end-in-itself.

The vertical scale schema is the basis for the spatial logics of the market and civic worlds (Johnson, 1987, p. 121-124; Lakoff, 1987, p. 458). The vertical scale schema is based 
on the material fact that when material objects are accumulated, they pile up, and the pile grows. Analogously, for resources such as money, the spatial logic is 'more is up' and 'less is down'. This schema emerges in expressions such as 'prices rose', 'stocks skyrocketed' and 'the market plummeted'. Therefore, people with resources are above people with less resources. The scale can manifest itself in a concrete spatial hierarchy, for example, a winner in sports gets the highest place in the middle of the podium. According to the logic of the market world, in an 'arena' or 'field', competition places everything in order, and 'aiming higher' sets people apart but benefits everybody. There can also be other resources than money, for example, knowledge. In the civic world, valued space is similar to a levelled public 'forum', and relative differences are seen as negative. Resources should be distributed evenly, and relations should be symmetric. Later, I illustrate with the empirical data the contrast between the hierarchic arenas in the market world and the levelled forums in the civic world. 


\begin{tabular}{|c|l|}
\hline Image schemas & Worlds of justification with opposite spatial logics \\
\hline Container & $\begin{array}{l}\text { Domestic world. Container: inward-oriented, internal order, } \\
\text { traditions, rules, outside is seen as a threat } \\
\text { World of renown. Container: outward-oriented, image, brand, } \\
\text { opinion of outsiders }\end{array}$ \\
\hline Source-path-goal & $\begin{array}{l}\text { Industrial world. Source-path-goal: space as means to an end, } \\
\text { reaching predefined goals } \\
\text { World of inspiration. Source-path-goal: space as an end-in-itself, }\end{array}$ \\
\hline $\begin{array}{l}\text { (Lakoff \& Johnson, 1999, p. 33) } \\
\text { celebrating the path, a journey into the unknown }\end{array}$ & $\begin{array}{l}\text { Civic world. Vertical scale: Levelled, equal, even, balanced, } \\
\text { symmetric, horizontal }\end{array}$ \\
\hline Vertical scale & Market world. Vertical scale: ordered, hierarchic, vertical \\
\hline
\end{tabular}

Table 2. Spatial logics and image schemas in the worlds of justification

Image schemas, such as source-path-goal, container and vertical scale, are 'extremely skeletal images that we use in cognitive operations' (Turner, 1991, p. 171). Image schemas are 'a representation one is left with when one has forgotten most of the details of an event' (Mandler, 2004, p. 81). Image schemas are topological which means that they can be made larger, smaller or distorted without changing them (Lakoff \& Johnson, 1999, p. 32; Talmy, 2000, p. 223-225). When people justify their views, they 'see' space according to these skeletal topological images and picture them in the language that they use. ${ }^{5}$ 
Next, I briefly depict the history of the local car-related disputes in Tampere and what contribution justification theory could have for first, the research on these local political disputes and second, more general critical and normative car-related research.

\section{Local disputes in Tampere and the research related to cars}

In this article, I use the dispute in Tampere to illustrate the spatial aspect of justification. Tampere is the third largest city in Finland with a little over 230000 inhabitants. There are ambitious aims to develop new traffic solutions in the city centre and to decrease the number of private cars on the road. One large underground parking lot has already been built under the city centre for almost 1000 cars and an even larger one is being built with yet another one planned for construction. Tampere has a brand new underground tunnel on the north side of the centre that is the longest one in Finland $(2.3 \mathrm{~km})$. (Finnish Transport Agency). In addition, there is a tramway being built (City of Tampere 2016). In the near future, new high-rise buildings and an ice hockey arena are to be constructed in the centre (City board of Tampere, 2015). One goal of these projects is to strengthen the position of Tampere as the most attractive city in Finland (City of Tampere 2017). However, because of the large-scale changes, traffic related disputes are polarized, and therefore, Tampere is a good site for research on controversies related to traffic. This polarization is evidenced by the following comment from the online discussion data based on one individual's experience.

'This topic of discussion amazed me again on how issues related to traffic cause so great "passion" among people living in Tampere. Whether it is travelling on foot, by bike or a car, skiing, running, etc., or whether it is about traffic on driveways, footpaths, in the woods or wherever, there is always quarrels and controversies. I have lived in Finland and abroad in several cities, and I read newspapers of different cities and read discussions in them, and I have never met that kind of intense quarrel on issues related to traffic.' (A3) 
Polarization has its roots in the history in Tampere. Traditionally, citizens and NGOs have promoted alternative traffic solutions, and only recently, increasing pedestrian zones has become an official objective of the city (see City board of Tampere, 2015). Before this stance, for decades, the city administration has promoted efficient and cost-effective American-style traffic solutions that enable economic growth, and in the 60 's, engineers even went to the United States to study them. People in future cities were seen as using only private cars, and no space was reserved for alternative means of transportation (Laine \& Peltonen, 2003, p. 95122.). Not until the 90 's, citizens were able to properly and publicly demand alternative means of transport; they argued that cars have negative ecological effects, many citizens oppose them (Laine \& Peltonen, 2003), they are not always the most rational technical solution (Ridell, 2009) and building new streets and bridges ruin the culturally and historically priceless local built environment (Pietilä, 2002). This plurality of values can be categorized by using worlds of justification, namely, these previous arguments are based on the world of ecology, civic world, industrial world and domestic world. Justification theory would offer a systematic framework for classifying the plurality of values with a limited number of categories (worlds of justification).

In case studies conducted in Tampere, researchers have studied the plurality of values related to cars, whereas in the general social sciences, researchers have taken a more normative stance. The critical position is strongly based on the civic world, which seems to have almost universal value. Social scientists have agreed that cars erode equality and public spaces. Not owning a car undermines the level of welfare (Bostock, 2001) and affects the ability to be a full member of society (Urry, 2004). In addition, cars atomize public space (Mitchell, 2005) and transform it into a mere route for passage (Sennett, 1974, p. 14-15; Sheller \& Urry, 2003, p. 114-115). 'Maximizing the flow of motorized traffic has eroded the free speech/free expression potential of public streets' (Blickstein, 2010, p. 889). However, 
the justification theory can offer a more pluralistic view. Urban space is not only a forum for public life (the civic world) but it can also be, for example, a passage through which people travel effortlessly and quickly (the industrial world). Next, I depict the online discussion data from the perspective of studying justification. I describe how and why online discussion data make it possible to study the plurality on values and spatial logics.

\section{Data and methodology}

The data of this article consist of five threads ${ }^{6}$ on the online discussion forum of a local newspaper, Aamulehti, which is situated in the city of Tampere. In 2016, Aamulehti had a circulation of 107477 (print and digital combined), the second largest of Finnish daily newspapers (MediaAuditFinland, 2016). On this online forum, threads develop under the news that is also published in the actual newspaper. In the research on the car-related political disputes in Tampere, Aamulehti has been used as a data source (Pietilä, 2002; Ridell, 2009), while the online forums have not been used as a data source. In the news under which the threads have developed, the head of Tampere city planning and a senior researcher of the Tampere University of Technology discuss the technical requirements in detail (A1 \& A5), and the manager of the Chamber of Commerce serves as a public representative of entrepreneurs (A3). In contrast, there is news regarding ordinary people who get involved in the online discussions (A2 \& A4).

The first comment was published in May 2011 (A1), and the last comment was published in August 2013 (A5) (Table 3). There are a total of 1175 comments. In the first days, the discussion is heated, because on average, $107(46 \%)$ comments were published on the first day, and $128(54 \%)$ comments were published later. These figures tell us how fast the dialogue evolved. However, the conversations do not last very long. The longest thread (A3) continues for nine days. Of the 1,175 comments, in a total of 755 or 64 percent, people take a 
stand, and they either criticize or advocate for the car-free street. Of these comments, 337 are critical (45\%), and 418 are favourable (55\%). Furthermore, of these comments, in 585, at least one world of justification can be distinguished (77\%). Often, one comment contains two or more worlds of justification. 


\begin{tabular}{|c|c|c|c|c|c|c|c|c|c|c|}
\hline $\begin{array}{l}\text { Title of news/thread } \\
\text { translated from Finnish } \\
\text { (abbreviation) }\end{array}$ & $\begin{array}{l}\text { Posts/ day } 1 . \\
\text { (date) }\end{array}$ & 2. & 3. & 4. & 5. & 6. & 7. & 8. & 9. & $\begin{array}{l}\text { Comb } \\
\text { ined }\end{array}$ \\
\hline $\begin{array}{l}\text { Even Buses May Be } \\
\text { Deported from } \\
\text { Hämeenkatu (A1) }\end{array}$ & $\begin{array}{l}141 \\
(6.5 .2011)\end{array}$ & 35 & 18 & 15 & 19 & 12 & 11 & & & 251 \\
\hline $\begin{array}{l}\text { The Plan for Hämeenkatu } \\
\text { Excites: Let's Demolish } \\
\text { the Center and Replace It } \\
\text { with Trees (A2) }\end{array}$ & $43(9.5 .2012)$ & 1 & 1 & & & & & & & 45 \\
\hline $\begin{array}{l}\text { The Chamber of } \\
\text { Commerce Wants a } \\
\text { Proper Pedestrian Center } \\
\text { without Buses in Tampere } \\
\text { (A3) }\end{array}$ & $\begin{array}{l}111 \\
(3.2 .2013)\end{array}$ & 62 & 32 & 32 & 32 & 9 & 16 & 5 & & 299 \\
\hline $\begin{array}{l}\text { 'Useless Waste of a Good } \\
\text { Street' - This is How } \\
\text { People Commented on the } \\
\text { Plan to Convert } \\
\text { Hämeenkatu to a } \\
\text { Pedestrian Street (A4) }\end{array}$ & $\begin{array}{l}111 \\
(29.3 .2013)\end{array}$ & 25 & 20 & 45 & 12 & 13 & 0 & 1 & 1 & 228 \\
\hline $\begin{array}{l}\text { Decision in the Fall: Will } \\
\text { Driving on Hämeenkatu } \\
\text { Be Terminated? (A5) }\end{array}$ & $\begin{array}{l}129 \\
(17.8 .2013)\end{array}$ & 58 & 41 & 28 & 31 & 41 & 19 & 5 & & 352 \\
\hline Combined & 535 & 181 & 112 & 120 & 94 & 75 & 46 & 11 & 1 & 1175 \\
\hline On average per day & 107 & 36.2 & 22.4 & 24 & 18.8 & 15 & 9.2 & 2.2 & 0.2 & 235 \\
\hline
\end{tabular}

Table 3. Titles of news/threads and number of posted messages 
I used Atlas.ti to categorize different themes and find patterns in the data. I used the worlds of justification as a framework. Some themes were difficult to categorize, for example, security may be associated with several worlds. Insecurity may originate from a problem in the industrial world if a technical error causes danger or from a problem in the domestic world if a person who violates the rules can cause a threat. As I read and categorized the data, I interpreted what kinds of visual and spatial logics and patterns participants use in their argumentation. I sketched spatial patterns in my mind and sometimes on paper that ordered arguments. I ended up with skeletal topological images, image schemas, which made clearly visible the differences and similarities between the worlds of justification.

In Tampere, citizens have not traditionally participated in traffic-related discussions, while experts and officials have communicated with one another (Laine \& Peltonen, 2003, p. 117-118). Only after the 90 's, this practise has started to change, partly because new local online forums have offered more dialogical interaction than newspapers and letters to the editor (Pietilä, 2001). In the news that is published in the actual newspaper and on the online forum of Aamulehti under which these threads develop, experts can express their views. However, on the online forum, people challenge the order of a so-called 'guaranteed city' in which the objectives and participatory procedures are strictly framed and delimited by experts (Pattaroni, 2015). Although local journalism is often not neutral in relation to interest groups because journalists try to maintain good relationships with their sources (Luhtakallio, 2012, p. $165-167,171)$, on online forums, people can challenge power structures and experiment with different types of justifications. Following online discussions provides a vivid image of the justification processes in which a community seeks a common direction where not only journalists and experts can interpret the world, and other than moderators, there are no gatekeepers. This method provides a rich picture of the spatial logics behind different worlds of justification. Although in newspapers, the news concerning peaceful manifestations are 
common (Luhtakallio, 2012, p. 165), the discussions on anonymous online forums often end up being heated despite moderation. In addition, in traffic-related discussions, people have very strong opinions (Aldred \& Jungnickel, 2013), which polarizes the debate. In the data of this study, in almost all the comments, the car-free street is clearly either criticised or advocated, and conciliatory comments are rare. For example, few car drivers admit that a ban on driving may entail some benefits. The right to move around the city by the means of one's own choice has great symbolic and practical importance.

Based on the analysis of the data, I analytically reduced the worlds of justification to three dichotomous pairs. These pairs of worlds of justification share the same image schemas (e.g., container, etc.) but opposite spatial logics (e.g., inward- or outward-oriented, etc.). In the data, the urban space is represented as either inward- (domestic) or outward-oriented (renown), either as a means to an end (industry) or an end-in-itself (inspiration), and either as a shared public forum (civic) or an arena for competition (market). Next, I illustrate these spatial logics and corresponding image schemas with empirical examples.

\section{An inward compared with an outward city (container)}

I utilize the container schema to interpret the opposite spatial logics of the domestic world and the world of renown. The domestic world is inward-oriented because the content of one's own familiar home environment and its traditions, order and rules are valued [Footnote7]. The world of renown is outward-oriented because the positive opinions of outsiders are valued. The advocates of a car-free street desire distinctive landmarks, such as car-free promenades, unlike the critics who do not believe a car-free street would make the city more visible or famous from an outside point of view. The whole idea of the car-free street is an external, international trend that threatens the familiar and unchanging nature of the domestic city. The parties use the container schema and represent the city as a container in opposite ways. Critics 
emphasise what is inside of the container, namely, domestic traditions and rules, and advocates emphasise outside opinion and renown, namely, improving the brand and image of Tampere and Finland.

Footnote7: This exemplifies the spatio-temporal logic of justification, as the home environment (space) and traditions (time) are valued and protected.

From the perspective of the advocates of a car-free city, the value of the city is evaluated from the outside. They want Finland to be perceived as a genuine part of Europe, and therefore, Hämeenkatu should be filled with 'pleasant, European-style cafés' (A4). They argue that different physical landmarks are crucial to the image of the city. For example, there is pedestrian zone 'in every big city, but Tampere is introverted and is not able to accomplish that' (A3). Tampere residents do not sufficiently care about what a city looks like from the outside. One advocate of a car-free street states that 'Hämeenkatu would be a monumentally magnificent pedestrian street. It would become one of Europe's greatest pedestrian streets. People far away would come to see it' (A1). From this perspective, landmarks and sights are valuable. Fame enables being proud of one's own hometown in the world of renown. However, many critics of a car-free Hämeenkatu argue that a pedestrian street would not be anything unique that people would come from far away to admire. They sarcastically present the need to create an image of a world-class metropolis and argue that the advocates (such as Finns typically) pay too much attention to what other people think of them.

'A metro could also be built because other metropolitan cities have one. Or train constructions hanging in the air as in Dortmund or Tokyo. More skyscrapers in the city centre and let's fix the harbour for large passenger ships. In addition, there is no proper old town with fortresses, etc. However, we could build it as a fake because we have not had one. It would attract tourists. Then, Tampere would start to look a bit like a real metropolis.' (A3) 
For the critics of a car-free Hämeenkatu, the internal domestic order, stability and traditions of the city, as a container, are inherently important unlike the image, brand or renown of the city from the perspective of outsiders. Instead of comparing Tampere to a 'real European city', they value what is 'real in Tampere'. According to the critics of a car-free Hämeenkatu, the city used to be full of shops and boutiques that had not changed in decades. When cars were banned on some smaller streets, the city began to be filled with bars and pubs. 'Hämeenkatu is full of cheap and shabby pubs, restaurants and shops. There is nothing authentic and original about Tampere' (A1). Threats are represented as coming from abroad, for example, international retail chains replace local shops, and foreign beggars and criminals threaten the conventional internal order of the city in the domestic world. This logic is based on the value of the inside of the city as a container.

\section{Urban space as a means to an end compared with space as an end-in-itself (source- path-goal)}

In the world of inspiration, space is valuable when it cannot be measured; instead, it should be a spontaneous source of unexpected experiences. What is valuable is to celebrate the journey in space or the space as an end-in-itself. To the contrary, in the industrial world, space is a means to ends. It is planned, controlled and measured to reach goals. The opposite spatial logics of these worlds are based on the source-path-goal schema. In the world of inspiration, the emphasis is on the path itself, and in the industrial world, the emphasis is on goals. The spatial logic of the industrial world can be seen in arguments in which the advocates of the car-free street suggest that a large quantity of cars blocking traffic is the city.

'In a cramped city centre, everybody has to get in front of the door of a store (where it fits only 3 or 4 cars due to the laws of physics) [ ... ] It is a Tampere kind of transport logic. Try to understand [...] cars cannot fit in a city centre, only a handful at a time. It is no one's fault but the law of geometry and mathematics.' (A2) 
Properly planned space enables the achieving of everyday goals efficiently, which requires limiting the number of cars in the city. However, according to the advocates of the car-free street, cars are not only objects that block movement in the city but also objects that make the city overly predictable. Driving a car does not enable experiencing the space as an end-initself. By walking, one can sense the atmosphere of the city and enjoy the space by using it for more than just a passage. Moving and spending time in urban space can offer novel experiences, for example, when 'bumping into' elements of nature or uncommon activities (such as an ice skating rink) in the middle of the city. On a pedestrian street, it is possible to 'meet friends, and sit in without being in a hurry' and visit stores that are 'colourful, small and decorated with graffiti' (A3). These elements can be positively surprising for urban flâneurs and hang-arounds and break the predictability of planned urban spaces and routes.

Alternatively, a city designed for cars is represented as grey and uninteresting. From this perspective, cars dissolve any personality or spirit of the city; they are only for going through the space and not for finding new things in the city.

'What about the cafes, think about cosy street cafes, where you can sip a good cup of coffee and watch the passing of walking people (no red, blue, yellow, green, grey, etc. cars) and notice how fine Art Nouveau style houses there are on the Hämeenkatu. '(A3)

However, from the point of view of the many critics of a car-free Hämeenkatu, cars are not boring and identical but rather 'a sight for sore eyes when people organize gatherings for old cars or American cars' (A1). Moreover, some critics say that they enjoy driving around the centre without predefined destinations. In this case, cars are not instruments for achieving goals but enablers of driving around the city as entertaining experience. In this type of argument, spatial reasoning is based on the source-path-goal schema with an emphasis on the path itself. However, mostly this logic and endless driving without any goals is questioned by the advocates of a car-free street and is represented as a useless waste of urban space. In the 
end, also the critics of a car-free street mostly argue for the practical qualities of the city. They, for example, emphasize the Finnish geographical constraints, such as cold winters. From this perspective, snow removal should be functional (industrial), and the construction of covered pedestrian zones and creation of a 'South European-style street culture' is impossible (inspiration). According to this logic, space is not for spending time or wandering in but rather mainly for passing through.

In the industrial world, a city develops in a direction that is calculated and planned by engineers and other experts. To the contrary, in the world of inspiration, development is in the hands of visionaries who search for new unimaginable directions for the city. The sourcepath-goal schema is used in this reasoning, namely, the valuable development of a city is either a predictable process towards the goals that are set by experts or a creative intuitive process of visionaries towards the unknown. As we can see, reasoning based on the sourcepath-goal schema is also temporal, as experts and visionaries approach the future city differently. In the arguments of the critics of a car-free street, creative visions for the future are not represented as valuable. These critics present the planners of the pedestrian street as "utopians who do not have a sense of reality and who have their "feet firmly in the air" (A5).

In the industrial world, cars either are positive devices that help people to get to destinations quickly and effectively or are negative roadblocks in cities, which are represented as cramped and crowded. In the world of inspiration, cars either can form an interesting, colourful sight, for example, in gatherings of vintage cars that move through the city, or can be a colourless mass that uses streets only as a passage to other places.

\section{Urban space as an arena for competition compared with a public forum (vertical scale)}

The spatial nature of the market and civic worlds can be interpreted by using vertical scale image schema. In the market world, space should allow the pursuit of private profit that 
increases in hierarchy. This competition of individuals, which places people in a hierarchical order, increases everyone's absolute standard of living. The city is an arena for this competition, and money is the most important resource that separates people. In the civic world, people do not compete for better positions in a hierarchical order; instead, relative differences are reduced. A city is a shared, levelled public forum.

Many critics of a car-free Hämeenkatu argue that regardless of, for example, wealth and place of residence, all people should have an equal right to move in the city. Cars guarantee this equality. If ordinary car drivers are excluded from the common urban space and, for example, are forced to drive in underground tunnels, the city is no longer for everybody but only for the few and wealthy elite who are on the top of not only the hierarchy in the market world but also the concrete city.

'As long as there are great halls and tower blocks in downtown, there is no need for the ordinary people to go there; they drive in the darkness of the tunnels just to pass the centre to drive to shopping centres outside the city. Fine buildings with the best views are built on the top of the tunnels. Who are they for? If it is necessary to run errands in the city, one goes straight from the tunnel to the darkness of a parking garage. The noble leadership of the city can proudly look at the amazing sight from the top of the roof of their white building.' (A1)

According to some critics of a car-free street, its advocates are privileged people, for example, “"urban designers" with high salaries' who "come up with "plans" that make the lives of citizens difficult' (A5). This argument is based on the logic of the civic world and not placing people in hierarchic order; however, critics also use the opposite logic of the market world. In addition to arguing for public and open spaces for all, some critics present that pedestrians, cyclists and people who use public transport are not sufficiently wealthy to make the city lucrative as a marketplace. A car is a sign of prosperity and a good position in the hierarchy, because 'money moves on wheels' (A1). 
Advocates of a car-free Hämeenkatu oppose the critics' idea of cars being signs of wealth and ability to consume that give people a right to the city. From this perspective, the problem is that car ownership separates people, because everybody does not have money for a car. This logic of the civic world is based on the idea that a city should not be a field for competition or an 'arena' but a meeting place that is a levelled 'forum' for everyone. A car is a status symbol that emphasises uneven economic relations, and 'in an underground parking garage few people see how well washed and shiny is the car you get out of' (A4). The advocates of a car-free street represent the critics mainly as members of privileged and wealthy marginal groups who are high in the hierarchy. If cars are prohibited, 'oil sheikhs, car importers and advertising agency bosses are very, very angry' (A1). However, the advocates of a car-free street also use the opposite logic of the market world. In addition to criticizing the fact that people are divided on the basis of wealth, they also criticize car drivers for not consuming enough: 'The faster the traffic is on a street, the less reasonable it is to stop in a shop.' (A4)

\section{Conclusion}

In the dispute about a car-free street in Tampere, Finland, the parties use versatile spatial reasoning as they justify their views. Participants draw upon different spatial logics, for example, representing the city as a container to contrast outside and inside the city, and thereby create graphic visualizations of contradictions between different values. Images, such as photographs, drawings and maps, are useful means to support justification (Blok \& Meilvang, 2015) and, similarly, images schemas, simple skeletal mental images of space (e.g., container), are powerful tools of justification. Boltanski and Thévenot (1999, p. 360-367) argue that, in justification processes, people rely on objects that create stability for the social order and serve as points of reference in disputes. However, it seems that the stability is not only in material objects but also in spatial patterns. Similar to objects at home or buildings in 
hometowns, the home as a closed and protected space maintains the domestic world.

By analysing the data, I have formed three dichotomous pairs that consist of opposite spatial logics. First, the parties want to protect the inside (domestic) or value the outside opinion (renown) of a city. Second, they either represent urban space as means to an end (industry) or an end-in-itself (inspiration). Third, they advocate for the city as a public forum (civic) or space as an arena for private competition (market). I have explained how these three types of opposite spatial logics are based on three different image schemas that people use in spatial reasoning. The domestic-renown pair is based on the container schema, because in the domestic world, the internal order, rules and traditions of home are protected from outside influences, and in the world of renown, outside opinion is crucial. The industrial-inspiration pair is based on the source-path-goal schema, because in the industrial world, achieving goals is important, and in the world of inspiration, the physical or mental path itself as a spontaneous journey without a known destination and spending time in the city are valued. The civic-market pair is based on the vertical scale image schema, because in the civic world, equal people are on the same level, and in the market world, resources set people in a hierarchic order.

In Tampere, both the advocates and critics of a car-free street use all forms of justifications although there are differences. For both sides, the industrial world is the most important world. In previous case studies conducted in Finland, the significance of industrial arguments has been addressed, especially in traffic-related disputes (Gladarev \& Lonkila, 2013, p. 387; Luhtakallio, 2012, p. 156-157). Especially the advocates of a car-free street also use justifications in the world of inspiration because they argue that cars make the city dull and predictable. In addition, advocates use justifications in the world of renown because they often argue for an outward-oriented, extroverted city with pedestrian zones that make the city special. However, critics use justifications in the domestic world, because they appreciate the 
internal order and traditions of the city and see outsiders mainly as a threat, for example, foreign retail chains that replace traditional businesses. In Finland, often older people value local traditions, and young people appreciate external influences (Wright, Purhonen, \& Heikkilä, 2013, p. 357). Moreover, for both sides, the market and civic worlds are important. From the perspective of the civic world, cars can reduce the differences in the accessibility of the city, especially in Finland where distances are long (Siren \& Hakamies-Blomqvist, 2004). In contrast, cars can make inequality visible because some people do not own cars, and some people are seen as showing off with expensive cars. In Finland, modesty and ordinariness are often valued (see Heinonen \& Autio, 2013). However, some people argue that in the market world, only cars make cities profitable because owning a car is a sign of wealth and the ability to buy and consume things.

The analysis of image schemas is not an exact science, such as geometry or topology, but is heavily based on interpretations similar to the analyses of language, discourses, etc. In this article, image schemas are the basis for visual interpretation, so-called heuristic diagrams for theorizing (Swedberg, 2016). They are not means to represent a finished theory; instead, they are open and enable novel ways to work the theory, to utilize the multimodality of thinking. Multimodality can take many forms. In addition to spatiality, multimodality can emerge also as temporality. For example, in the industrial world, future goals are reached efficiently, and in the inspirational world, visionary paths lead into an unimaginable future. Moreover, instead of image schemas, visuospatial reasoning and metaphors can be based on sensual qualities of space, such as lightness. For example, in the market world, an elite is not only above others but sits on 'the top of the roof of their white building' (AL1) as ordinary people are forced underground in the darkness of tunnels and parking garages.

In the future, the spatial character of justification theory can be examined in more detail. This can make it more applicable and relevant from the perspective of, for example, 
urban research, planning theory and geography. In this article, the spatiality of the examined case is obvious; however, disputes related to topics that are less clearly spatial can also be analysed from the visuospatial perspective. In addition to describing actual physical spaces, image schemas are used to represent space figuratively, in other words, to create visuospatial metaphors to justify values related to abstract subjects, such as business (see Boltanski \& Thévenot, 2006, p. 151-158). For example, innovative business leadership can be depicted as being on an inspiring path, which is metaphorical rather than concrete, or condescending executives can be negatively pictured as being high-and-mighty on the top of the organization, far above subordinates (although both would actually be on the same floor) (see Gagnon et al., 2011, p. 8). Visuospatial metaphors are powerful tools in argumentation. Advancing the spatial aspect of justification theory offers a novel way to look at all controversies, including those that seem non-spatial.

\section{Endnotes}

1. A world of justification is a concept that is based on a very broad spatial metaphor because a 'world' encloses everything and is separate from every other world morally, materially and spatially.

2. In this article, I focus on the original six worlds of justification. In the future, the spatial aspect of other worlds of justification and Thévenot's (2005) regimes of engagement can be examined.

3. I focus on the plurality of the image schemas behind the spatial logics of the worlds of justification. I do not focus on the internal binaries as such (inward compared with outward) or why people order the world through binary oppositions.

4. The concept of image schema has been used in linguistics, psychology, philosophy, computer science and neuroscience. Originally, in cognitive linguistics, the concept was utilized in the analysis of expressions, idioms, metaphors, etc. (Johnson, 1987; Lakoff, 1987; Lakoff \& Johnson, 1980). In this article, the unit of analysis is a justification.

5. Turner (1991, p. 99-120) and Oakley (2005) have analysed image schemas in political argumentation, and they use so-called force dynamic schema to show that when people argue, 
they 'struggle for space', 'force or push each other away', 'block or support each other', etc. Related to this vocabulary is the metaphor 'argument is war' because people who argue 'attack each other', 'try to win', 'have targets and strategies', etc. (Lakoff \& Johnson, 1980, p. 4). This approach is parallel with Bourdieu's (1996, p. 9-10) concept of field, which is based on a spatial metaphor. Fields are physical force fields and fields for competition. However, in this article, I do not focus on argumentation only as a struggle of opposite forces but instead, on the plurality of image schemas that people commonly recognize and value and therefore utilize in disputes to criticize or convince others.

6. I use the following abbreviations for the threads: A1, A2, A3, A4 and A5.

\section{References}

Alapuro, R., \& Lonkila, M. (2012). Political culture in Russia from a local perspective. In R. Alapuro, A. Mustajoki, \& P. Pesonen (Eds.). Understanding Russianness (pp. 111124). London: Routledge.

Albertsen, N., \& Diken, B. (2001). Mobility, justification, and the city. Nordisk Arkitekturforskning, 14(1), 13-24.

Aldred, R., \& Jungnickel, K. (2013). Matter in or out of place?: Bicycle parking strategies and their effects on people, practices and places. Social \& Cultural Geography, 14, 604 624. doi:10.1080/14649365.2013.790993

ANFAC (2014). Vehicles in Use (2009-2014). Retrieved from www.acea.be/uploads/statistic_documents/ACEA_PARC_2014_v3.pdf

Barnett, C. (2014). Geography and ethics III: From moral geographies to geographies of worth. Progress in Human Geography, 38, 151-160. doi:10.1177/0309132513514708

Blickstein, S. (2010). Automobility and the politics of bicycling in New York City. International Journal of Urban and Regional Research, 34, 886-905. doi:10.1111/j.1468-2427.2010.00914.x

Blok, A. (2013). Pragmatic sociology as political ecology: On the many worths of nature(s). European Journal of Social Theory, 16, 492-510. doi:10.1177/1368431013479688

Blok, A., \& Meilvang, M. L. (2015). Picturing urban green attachments: Civic activists moving between familiar and public engagements in the city. Sociology, 49, 19 37. doi:10.1177/0038038514532038

Boltanski, L., \& Chiapello, È. (2007). The new spirit of capitalism. London: Verso. 
Boltanski, L., \& Thévenot, L. (1999). The sociology of critical capacity. European Journal of Social Theory, 2, 359-377. doi:10.1177/136843199002003010

Boltanski, L., \& Thévenot, L. (2006). On justification: Economies of worth. Princeton \& New Jersey: Princeton University Press.

Bostock, L. (2001). Pathways of disadvantage?: Walking as a mode of transport among low income mothers. Health and Social Care in the Community, 9, 11-18. doi:10.1046/j.1365-2524.2001.00275.x

Bourdieu, P. (1996). The rules of art: Genesis and structure of the literary field. Stanford: Stanford University Press.

City board of Tampere (2015). Five star city centre: Tampere city development programme 2015-2030. Retrieved from http://www.tampere.fi/tiedostot/f/7buwGUnyn/tamperecitycentredevelopmentprogram mesummary.pdf

City of Tampere (2016). Tampere to receive a tramway. Retrieved from https://www.tampere.fi/en/transport-and-streets/tramway.html

City of Tampere (2017). Humane and attractive Tampere. Lauri Lyly's Mayor's programme for 2017-2021. Retrieved from https://www.tampere.fi/tiedostot/h/quOqfpzK9/Pormestarin_ohjelma_englanti.pdf

Dant, T., \& Martin, P. J. (2001). By car: Carrying modern society. In J. Gronow \& A. Warde (Eds.), Ordinary consumption (pp. 143-158). London: Routledge.

Fuller, C. (2012). Urban politics and the social practices of critique and justification: Conceptual insights from French pragmatism. Progress in Human Geography, 37, 639-657. doi:10.1177/0309132512469763

Gagnon, S. A., Brunyé, T. T., Robin, C., Mahoney, C. R., \& Taylor, H. A. (2011). High and mighty: Implicit associations between space and social status. Frontiers in Psychology, 2 (October), 1-10. doi:10.3389/fpsyg.2011.00259

Gladarev, B., \& Lonkila, M. (2013). Justifying civic activism in Russia and Finland. Journal of Civil Society, 9, 375-390. doi:10.1080/17448689.2013.844450

Heinonen, V., \& Autio, M. (2013). The Finnish consumer mentality and ethos: In the intersection between east and west. In V. Heinonen \& M. Peltonen (Eds.), Finnish consumption!: An emerging consumer society between east and west (pp. 42-85). Helsinki: The Finnish Literature Society. 
Holden, M., \& Scerri, A. (2015). Justification, compromise and test: Developing a pragmatic sociology of critique to understand the outcomes of urban redevelopment. Planning Theory, 14, 360-383. doi:10.1177/1473095214530701

Johnson, M. (1987). The body in the mind: The bodily basis of meaning, imagination, and reason. Chicago: The University of Chicago Press.

Laine, M., \& Peltonen, L. (2003). Ympäristökysymys ja aseveliakseli: Ympäristön politisoituminen Tampereella vuosina 1959-1995. Tampere: Tampereen yliopisto. Retrieved from http://uta32-kk.lib.helsinki.fi/bitstream/handle/10024/67286/951-445657-2.pdf?sequence $=1$

Lakoff, G. (1987). Women, fire, and dangerous things: What categories reveal about the mind. Chicago: The University of Chicago Press.

Lakoff, G., \& Johnson, M. (1980). Metaphors we live by. Chicago: University of Chicago Press.

Lakoff, G., \& Johnson, M. (1999). Philosophy in the flesh: The embodied mind and its challenge to western thought. New York: Basic.

Latour, B. (1998). To modernize or to ecologize?: That is the question. In B. Braun \& N. Castree (Eds.), Remaking Reality: Nature at the Millenium (pp. 220-241). London \& New York: Routledge.

Finnish Transport Agency. Rantatunneli: breeding ground for the city. Retrieved from https://www2.liikennevirasto.fi/rantatunneli/en/\#.WhWYX2i0PIU

Luhtakallio, E. (2012). Practicing democracy: Local activism and politics in France and Finland. Basingstoke: Palgrave Macmillan.

Mailhot, C., Gagnon, S., Langley, A., \& Binette, L. F. (2016). Distributing leadership across people and objects in a collaborative research project. Leadership, 12, 53-85. doi: $10.1177 / 1742715014543578$

Mandler, J. M. (2004). The foundations of mind: Origins of conceptual thought. Oxford: Oxford University Press.

MediaAuditFinland (2016). LT ja JT tarkastustilasto 2016. Retrieved from http://mediaauditfinland.fi/wp-content/uploads/2017/06/Levikkitilasto-2016.pdf

Mitchell, D. (2005). The S.U.V. model of citizenship. Floating bubbles, buffer zones, and the rise of the 'purely atomic' individual. Political Geography, 24, 77-100. doi:10.1016/j.polgeo.2004.06.003 
Oakley, T. (2005). Force-dynamic dimensions of rhetorical effect. In B. Hampe (Ed.), From perception to meaning: Image schemas in cognitive linguistics. Berlin \& New York: Mouton de Gruyter.

Oldenhof, L., Potsma, J., \& Putters, K. (2014). On justification work: How compromising enables public managers to deal with conflicting values. Public Administration Review, 74, 52-63. doi:10.1111/puar.12153

Pattaroni, L. (2015). Difference and the common of the city: The metamorphosis of the "Political" from the urban struggles of the 1970's to the contemporary urban order. In J. Resende \& A. Martins (Eds.), The making of the common in social relations (pp. 141-172). Cambridge: Cambridge Scholars Publishing.

Pietilä, V. (2001). Yleisönosasto ja Internet keskusteluareenoina. Tiedotustutkimus, 24(2), 18 33.

Pietilä, V. (2002). Siltasotaa Tampereella: Julkinen keskustelu Koskenniskan siltahankkeesta. Kunnallistieteellinen aikakauskirja, 30, 136-153.

Ridell, S. (2009). Maankäyttöpeliä uutistilassa: Sanomalehti paikallisten kamppailujen julkisena areenana. In S. Ridell, P. Kymäläinen, \& T. Nyyssönen (Eds.). Julkisen tilan poetiikkaa ja politiikkaa: Tieteidenvälisiä otteita vallasta kaupunki-, media- ja virtuaalitiloissa (pp. 240-269). Tampere: Tampere University Press.

Sennett, R. (1974). The fall of public man. Cambridge: Cambridge University Press.

Sheller, M., \& Urry, J. (2003). Mobile transformations of 'public' and 'private' life. Theory, Culture \& Society, 20(3), 107-125. doi:10.1177/02632764030203007

Silber, I. F. (2003). Pragmatic sociology as cultural sociology: Beyond repertoire theory? European Journal of Social Theory, 6, 427-449. doi:10.1177/13684310030064004

Siren, A., \& Hakamies-Blomqvist, L. (2004). Private car as the grand equaliser?: Demographic factors and mobility in Finnish men and women aged 65+. Transportation Research Part F: Traffic Psychology and Behaviour, 7, 107-118. doi:10.1016/j.trf.2004.02.003

Swedberg, R. (2016). Can You Visualize Theory? On the Use of Visual Thinking in Theory Pictures, Theorizing Diagrams, and Visual Sketches. Sociological Theory, 34, 250275. http://doi.org/10.1177/0735275116664380

Talmy, L. (2000). Toward a cognitive semantics: Volume I, concept structuring systems. Cambridge (Mass.): MIT Press. 
Thévenot, L. (2001). Organized complexity: Conventions of coordination and the composition of economic arrangements. European Journal of Social Theory, 4, 405-425. doi: $10.1177 / 13684310122225235$

Thévenot, L. (2002). Which road to follow?: The moral complexity of an 'equipped' humanity’. In J. Law \& A. Mol (Eds.), Complexities: Social studies of knowledge practices (pp. 53-87). Durham: Duke University Press.

Thévenot, L. (2005). Pragmatic regimes governing the engagement with the world. In K. Knorr-Cetina, T. R. Schatzki, \& E. Von Savigny (Eds.). The practice turn in contemporary theory (pp. 64-82). London: Routledge.

Thévenot, L. (2007). The plurality of cognitive formats and engagements. Moving between the familiar and the public. European Journal of Social Theory, 10, 409-423. doi:10.1177/1368431007080703

Thévenot, L. (2014). Voicing concern and difference: From public spaces to common-places. European Journal of Cultural and Political Sociology, 1, 7-34. doi:10.1080/23254823.2014.905749

Thévenot, L., Moody, M., \& Lafaye, C. (2000). Forms of valuing nature: Arguments and modes of justification in French and American environmental disputes. In M. Lamont \& L. Thévenot (Eds.), Rethinking comparative cultural sociology: Repertoires of evaluation in France and the United States (pp. 229-272). Cambridge: Cambridge University Press.

Thrift, N. (2004). Driving in the city. In M. Featherstone, N. Thrift, \& J. Urry (Eds.), Automobilities (pp. 41-59). London: Sage.

Statistics Finland (2013). Ajoneuvokanta kasvoi vuonna 2012. Retrieved from http://tilastokeskus.fi/til/mkan/2012/mkan_2012_2013-03-22_tie_001_fi.html

Turner, M. (1991). Reading minds: The study of English in the age of cognitive science. Princeton (N.J.): Princeton University Press.

Urry, J. (2004). The system of automobility. In M. Featherstone, N. Thrift. \& J. Urry (Eds.), Automobilities (pp. 25-39). London: Sage.

Wright, D., Purhonen, S., \& Heikkilä, R. (2013). Comparing 'cosmopolitanism': Taste, nation and global culture in Finland and the UK. Comparative Sociology, 12, 330-360. doi:10.1163/15691330-12341266

Yamaguchi, T., \& Suda, F. (2010). Changing social order and the quest for justification: GMO controversies in Japan. Science, Technology \& Human Values, 35, 382-407. doi:10.1177/0162243909345837 